\title{
Catalonia: Two Tales of Governance against the Law
}

\author{
Aurelia Colombi Ciacchi \\ Editor-in-Chief EJCL; Professor of Law and Governance, Academic \\ Director Groningen Centre for Law and Governance, University of Groningen, \\ The Netherlands \\ a.l.b.colombi.ciacchi@rug.nl
}

The recent political events in Catalonia have taken the other European countries by surprise. Why did Carles Puigdemont push so hard on the Spanish government and organised an illegal unilateral referendum on Catalonia's independence? And why did the Spanish government push so hard back, using so much unnecessary - and therefore unlawful - violence against the Catalan voters?

How could the Catalan separatists believe that the European Union would be able and willing to defend them against the Spanish government? How could they believe that the Catalan citizens would become economically more prosperous after a declaration of independence? Why did they not foresee that banks and other powerful business actors would immediately move their headquarters out of Catalonia and make the region economically weaker? Was the pound crash and the dramatic fall of the UK house prices after Brexit not clear enough a lesson? ${ }^{1}$

And what about the Catalan separatists who are now withdrawing symbolic amounts of cash from the five main bank chains, as a sign of protest? ${ }^{2}$ How can

1 See F. O'Brien, 'UK house prices fall for fifth month in a row' (Independent, 20 September 2017). Retrieved on 20 October 2017, http://www.independent.co.uk/news/business/news/ uk-house-prices-latest-news-fall-housing-market-property-buying-selling-renting-a 795654 .html.

2 "Some protesters made symbolic withdrawals of 155 EUR - a reference to Article 155 of the Spanish Constitution, which the Spanish Government is now using to start imposing direct rule over semi-autonomous Catalonia (...). Others were opting for 1,714 E U R in a nod to 1714, a highly symbolic date for independence supporters marking the capture of Barcelona by the troops of king Felipe V, who then moved to reduce the rights of rebellious regions". See J. Badcock, 'Spain to force elections in Catalonia in Article 155 crackdown on independence leaders' (The Telegraph, 20 October 2017). Retrieved on 20 October 2017,

(C) CIACCHI, 2017 | DOI 10.1163/22134514-00404005

This is an open access article distributed under the terms of the prevailing CC-BY-NC license at the time of publication. 
they seriously believe this could induce the banks or the European Union to change their minds? ${ }^{3}$

The recent developments in Catalonia could be seen as two tales of governance against the law. The first tale sees the Catalan strive for self-governance and new governance as protagonist, while in the second tale the classic topdown, old governance in the form of command and control by the State power takes the lead. ${ }^{4}$ Both governance actors crossed the boundaries of legality. While the illegal acts of the Catalan separatists could be seen as acts of civil disobedience, ${ }^{5}$ the unnecessary violence of the Spanish police is just a classic example of unlawful abuse of public power.

A good analysis of the causes of the recent conflict is provided by the major of Barcelona, Ada Colau: she sees the origins of the current crisis "in the repeated refusals on the part of the government in Madrid to enter a dialogue on Spanish territorial reforms that recognise the rights of Catalans to decide their own political future". ${ }^{6}$ On the independence referendum, she writes: "There are many non-separatists such as ourselves, who, while critical of the unilateral path taken by the Catalan regional government, are calling for a negotiated solution in accordance with the feelings of $82 \%$ of the Catalan population, who support the holding of an agreed referendum, like the one conducted in Scotland." ${ }^{7}$

However, the Spanish government did not allow an agreed referendum. Fuelled by an irritated public opinion on both sides of the battlefield, the conflict escaled in illegal conducts on both sides: the illegal referendum, and the

http://www.telegraph.co.uk/news/2017/10/20/spain-force-elections-catalonia-article -155-crackdown-independence/.

3 Even the major of Barcelona, Ada Colau, who in 2011 took part in protests against the World Bank, thinks the Catalan separatists' call to withdraw money "was probably not the smartest idea”. See 'Catalans make symbolic cash withdrawals' (DW, 20 October 2017). Retrieved on 20 October 2017, http://www.dw.com/en/catalans-make-symbolic-cash-withdrawals/ a-41047384.

4 On 'new' vs 'old' governance see J. Richardson, 'New Governance or Old Governance? A Policy Style Perspective', in D. Levi-Faur (ed), The Oxford Handbook of Governance (Oxford University Press, 2012) 311.

5 See G. Tremlett, 'A day of celebration or violence? Catalonia prepares for reckoning' (The Guardian, 30 September 2017). Retrieved on 20 October 2017, https://www.theguardian .com/world/2017/sep/3o/day-celebration-or-violence-catalonia-independence-referendum: "an exercise in mass civil disobedience".

6 A. Colau, 'Europe must act to protect the rights and freedoms of Catalans' (The Guardian, 27 September 2017). Retrieved on 20 October 2017, https://www.theguardian.com/ commentisfree/2017/sep/27/europe-must-act-to-protect-rights-and-freedoms-of-catalans.

7 Ibid. 
unlawful violence against the Catalan voters. Who will curb the escalation now? ${ }^{8}$ The question unfortunately remains open.

(This Editorial was sent to the publisher on 20 October 2017. The spectacular political events occurred after this date, including the imprisonment of eight former Catalan government members, could unfortunately not be considered here.)

8 I.G. Perez, 'Who Will Curb Escalation in Catalonia?' (The Beaver, 10 October 2017). Retrieved on 20 October 2017, https://beaveronline.co.uk/who-will-curb-escalation-in-catalonia/. 